\section{Plant Size Influences Bell Pepper Seed Quality and Yield}

\author{
Victor M. Sanchez', F.J. Sundstrom', and N. Suzanne Lang \\ Department of Horticulture, Louisiana Agricultural Experiment Station, \\ Louisiana State University Agricultural Center, Baton Rouge, LA 70803 \\ Additional index words. plant density, assimilate export rate, $\mathrm{C}$ exchange rate, \\ Capsicum annuиm
}

Abstract. This study investigated the influence of plant size, as determined by plant density, and fruit load variation on the production and quality of bell pepper (Capsicum annuum L.) seeds. Six-week-old 'Resistant Giant no. 4' bell pepper seedlings were transplanted 15, 30,45 , and $60 \mathrm{~cm}$ apart. Plants spaced $45 \mathrm{~cm}$ apart were not thinned or were thinned to one or three fruit per plant. Pepper plants grown at low plant densities produced larger fruit and seeds that germinated faster and at higher percentages than plants grown at higher densities. Assimilate export rate (AER) increased linearly with plant spacing. At harvest, $\mathrm{C}$ exchange rate (CER) and AER of plants with nonthinned fruit loads were $\approx 300 \%$ and $500 \%$ higher, respectively, than those of plants with one or three fruit. Fruit thinning decreased CER and AER; however, seeds produced by plants with one or three fruit had significantly higher germination percentages than plants with full fruit loads. These observations suggest that the high CERS of smaller plants with nonthinned fruit loads may have been insufficient to compensate completely for the higher sink demands. Therefore, crop cultural practices that increase the ratio of pepper plant size to total fruit count may increase the quality of seeds produced by those plants.

There is little information about the effects of plant size, as determined by plant density, on bell pepper seed quality. Fruit thinning and high soil nutrient levels can increase bell pepper seed yield and quality (van Uffelen, 1984, 1986). Fruit from the lower parts of pepper plants produced seeds with higher dry weight and superior germination characteristics compared with fruit set later in development (Osman et al., 1984). Thinning treatments also have reduced net photosynthesis within hours or days in peppers (Kriedemann et al., 1976). When bell pepper plants were subjected to fruit thinning and branch removal, total seed yields were not affected (Nielsen and Veierskov, 1988). Removing the earliest flowers

Received for publication 11 Nov. 1992. Accepted for publication 19 Mar. 1993. Louisiana Agricultural Experiment Station journal series paper 91-28-5343. The cost of publishing this paper was defrayed in part by the payment of page charges. Under postal regulations, this paper therefore must be hereby marked advertisement solely to indicate this fact.

'Current address: Integrated Coating and Seed Technology, 1293 Harkins Rd., Salinas CA 93901 from pepper plants increased fruit and seed yields (Wang et al., 1982).

Bell peppers can fix $\mathrm{C}$, but provide only $\approx 13 \%$ of the total assimilates; the rest is translocated from primary axis leaves (Steer and Pearson, 1976). Cultural practices can affect carbohydrate partitioning in plants. Thinning pepper plants reduced sink load; consequently, stem and leaf dry weights increased when fewer fruit developed (Nielsen and Veierskov, 1988). Removing flowers from bell pepper plants increased the concentrations of stored carbohydrates in stems (Hall, 1977).

The purpose of this study was to investigate the effect of pepper plant size fruit load manipulation on seed quality and on plant $\mathrm{C}$ exchange rate (CER) and assimilate export rate (AER).

'Resistant Giant no. 4' bell peppers were seeded in a peat-like medium in Todd planter flats in the greenhouse in Spring 1988 and 1989. After 6 weeks, the seedlings were hardened and transplanted to the field. The soil was an Olivier silt loam (fine-silty, mixed, thermic aquic, Fragiudalf) with $0.60 \%$ organic matter and a $\mathrm{pH}$ of 6.3 .
All plots received a preplant band application of $8 \mathrm{~N}-0.1 \mathrm{P}-0.2 \mathrm{~K}$ at a rate of $636 \mathrm{~kg} \cdot \mathrm{ha}^{-1}$, 10 to $12 \mathrm{~cm}$ under row center, and $67 \mathrm{~kg}$ of ammonium nitrate $\left(\mathrm{NH}_{4} \mathrm{NO}_{3}\right)$ /ha as a sidedressing 3 weeks after transplanting and immediately after fruit set started. Seedlings were transplanted in rows $1.2 \mathrm{~m}$ apart in a completely randomized design. Plant manipulation was performed by varying plant density and fruit load.

Plant density study. This study began in Spring 1988 and was repeated in Spring 1989. Four in-row plant spacing treatments $(15,30$, 45 , and $60 \mathrm{~cm}$ ) with 10 plants per treatment were applied at random within each of eight rows. At $\approx 50$ days postanthesis, five plants per treatment were chosen randomly and destructively harvested. Stems, leaves, and fruit of each plant were separated in the laboratory for measurement. Plant leaf area was recorded on an area meter (Delta-T Devices, Cambridge, England). Plant dry weight was measured on leaves and stems after drying at $70 \mathrm{C}$ for $48 \mathrm{~h}$. The total number and fresh weight of green and red marketable fruit also were recorded.

Seeds were extracted immediately from marketable red fruit and allowed to surface-dry for $24 \mathrm{~h}$ at $25 \mathrm{C}$. Only those seeds that passed through a 4-mm sieve, but were unable to pass through a 3-mm standard testing sieve (American Society for Testing and Materials index), were used to measure dry weight and test germination. Dry weight (based on percentage of fresh weight) was recorded after seeds were dried at $75 \mathrm{C}$ for $24 \mathrm{~h}$. Germination tests consisted of eight replications of 50 seeds placed in $90-\mathrm{mm}$ petri dishes on one layer of Whatman no. 2 filter paper moistened with $4 \mathrm{ml}$ of distilled water. All petri dishes were placed in dark incubators at $25 \mathrm{C}$. Germinated seeds were counted daily under light for 15 days. Seeds were considered germinated at the first sign of radicle protrusion. Germination percentage, mean time to germination (MTG) [MTG $=$ day number $(\mathrm{T}) \times$ number of seed germinated $(\mathrm{N})+\mathrm{T}_{2} \mathrm{~N}_{2}+\ldots+\mathrm{TnN}_{\mathrm{n}} /$ (total number of seed germinated)], and the mean number of days for radicle emergence were calculated as described by Edwards and Sundstrom (1987). A tetrazolium assay (Grabe, 1970) for viability was performed on any seeds that had not germinated after 15 days.

Fruit load study. Based on the results of the preliminary 1988 plant density study (Sanchez, 1989), this study was designed to determine if seed quality was influenced by the number of 
fruit per plant. 'Resistant Giant no. 4' seedlings were hardened and transplanted at a 45$\mathrm{cm}$ within-row spacing in a completely randomized design. There were three fruit load treatments: 1) thinning all fruit except one per plant, 2) thinning all fruit except three per plant, and 3) no thinning (control). Treatments were applied randomly at anthesis, and fruit were removed about every 10 days until harvest. At harvest, five plants per treatment were selected at random, destructively harvested, and measured as previously described. Only seeds from red fruit were used for measurements.

CER and AER. In 1989, CER and AER were measured on pepper plants at anthesis in the plant density study and at anthesis and harvest in the fruit load study. In the plant density study, measurements at harvest could not be recorded due to unfavorable field conditions. In the fruit load study, fruit removal began $\approx 1$ week before CER and AER measurements were able to be taken due to unfavorable field conditions.

CER was measured on fully expanded source leaves that subtended developing fruit. Measurements were made using a portable infrared gas analyzer (model 6200; LI-COR, Lincoln, Neb.) at an ambient $\mathrm{CO}_{2}$ concentra-

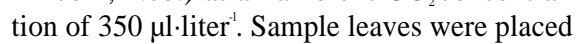
in a 0.25-liter cuvette, and ambient air was passed over the adaxial and abaxial leaf surfaces at a flow rate of $1100 \mu \mathrm{mol} \cdot \mathrm{s}^{-1}$. Differences in $\mathrm{CO}_{2}$ concentration between air supplied to the leaf and exhausted air were measured in clear sky conditions. All measurements were made near midday. CER was calculated using the method of Hesketh and Moss (1963) and expressed as milligrams of $\mathrm{CH}_{2} \mathrm{O}$ per square decimeter per hour.

AER was estimated on the same source leaves as those used to measure CER following the method of Terry and Mortimer ( 1972). Four leaf disks (each $0.5 \mathrm{~cm}$ in diameter) were removed from sample leaves at the beginning and end of the 5-h sampling interval (time, = 0900 and time $_{2}=1400 \mathrm{HR}$ ). Leaf disks were freeze-dried and weighed. AER rates were calculated as estimates based on net CER and dry weight change per unit leaf area during the sampling interval $\left[\right.$ AER $=(\mathrm{CER})-\left(\mathrm{dry}_{\mathrm{wt}} \mathrm{t}_{\text {tine } 2}\right.$ - dry $\left.\mathrm{wt}_{\text {timel }}\right)$ ].

In both studies, all germination and viability percentage data were arcsin-transformed, and MTG data were log-transformed before analysis using SAS's (1985) general linear model procedure. Only nontransformed data are presented for ease of interpreting the tables. In the plant density study, year significantly interacted with some dependent variables. Trends between 1988 and 1989 data were similar, so only 1989 representative data are presented with the regression analysis. In the fruit load study, means were separated by least significant difference.

Effects of plant density. Plant density significantly affected pepper plant leaf area and fruit yield (Table 1). Plant leaf area, dry weight, and red and total fruit count per plant increased linearly with plant spacing. As found by Palevitch (1969) and Saamin (1978), red fruit weight was not significantly affected by density. The ratio of leaf area to total fruit count did not vary significantly between plant spacings, a result indicating that larger plants did not have a greater ability to partition photoassimilates to developing seeds than smaller plants,

The total seed count in red fruit produced by each plant was influenced significantly by plant population (Table 2). Larger plants produced more seeds. Plants spaced at $45 \mathrm{~cm}$ produced $96 \%$ of the viable seeds that germinated faster and at higher percentages than those at other spacings (Table 2). At anthesis, there were no significant differences in CER, but AER increased linearly as plant spacing increased (data not shown). Average AER in 15- and 30-cm spacing treatments was 6.33 mg $\mathrm{CH}_{2} \mathrm{O} / \mathrm{dm}^{2}$ per $\mathrm{h}$ vs. an average AER in 45and $60-\mathrm{cm}$ spacing treatments of $7.33 \mathrm{mg}$ $\mathrm{CH}_{2} \mathrm{O} / \mathrm{dm}^{2}$ per $\mathrm{h}$.

Linear correlation coefficient values indicated that plant spacing correlated significantly $(P \leq 0.01)$ with plant leaf area and dry weight $(r=0.28$ and 0.70 , respectively). Plant dry weight correlated positively $(P \leq 0.01)$ with germination percentage $(r=0.31)$ and inversely with MTG $[r=(-0.27)]$.

Effects of fruit load. A second study was initiated to investigate 1) whether plants of

Table 1. Influence of plant spacing on bell pepper plant leaf area and weight, total marketable green and red fruit number, and red fruit weight.'

\begin{tabular}{|c|c|c|c|c|c|c|}
\hline $\begin{array}{l}\text { Within-row } \\
\text { spacing }(\mathrm{cm})\end{array}$ & $\begin{array}{l}\text { Leaf area } \\
\left(1000 \mathrm{~cm}^{2}\right)\end{array}$ & $\begin{array}{l}\text { Plant dry } \\
\text { ) wt }(\mathrm{g})\end{array}$ & $\begin{array}{c}\text { Total fruit/ } \\
\text { plant (no.) }\end{array}$ & $\begin{array}{l}\text { Red fruit/ } \\
\text { plant (no.) }\end{array}$ & $\begin{array}{c}\text { Red fruit } \\
\text { wt (g) }\end{array}$ & $\begin{array}{c}\text { Leaf area : } \\
\text { total no. } \\
\text { fruit ratio }\end{array}$ \\
\hline 15 & 3.86 & 46.5 & 6.6 & 1.8 & 261 & 671 \\
\hline 30 & 5.34 & 67.0 & 8.4 & 2.0 & 333 & 818 \\
\hline 45 & 6.21 & 103 & 11.6 & 2.7 & 401 & 566 \\
\hline 60 & 7.05 & 105 & 12.4 & 2.7 & 376 & 686 \\
\hline \multicolumn{7}{|l|}{ Significance } \\
\hline Linear & $* *$ & ** & ** & $* *$ & NS & NS \\
\hline Quadratic & NS & $*$ & NS & NS & NS & NS \\
\hline
\end{tabular}

${ }^{2}$ Means of 1989 data only.

Ns,*** Nonsignificant or significant at $P \leq 0.05$ or 0.01 , respectively.

Table 2. Influence of plant spacing on characteristics of seeds extracted from red bell peppers?

\begin{tabular}{|c|c|c|c|c|c|c|}
\hline \multirow[b]{2}{*}{$\begin{array}{l}\text { Within-row } \\
\text { spacing }(\mathrm{cm})\end{array}$} & \multicolumn{4}{|c|}{ Seed } & \multirow[b]{2}{*}{$\begin{array}{l}\text { MTG }^{y} \\
\text { (days) }\end{array}$} & \multirow[b]{2}{*}{$\begin{array}{c}\text { Viability } \\
(\%)\end{array}$} \\
\hline & $\begin{array}{l}\text { Per plant } \\
\text { (no.) }\end{array}$ & $\begin{array}{l}\text { Per fruit } \\
\text { (no.) }\end{array}$ & $\begin{array}{c}\text { Dry } \\
\text { wt (mg) }\end{array}$ & $\begin{array}{c}\text { Germination } \\
(\%)\end{array}$ & & \\
\hline 15 & 275 & 159 & 7.5 & 73 & 6.3 & 86 \\
\hline 30 & 385 & 195 & 7.3 & 63 & 7.1 & 83 \\
\hline 45 & 417 & 157 & 7.6 & 88 & 5.0 & 96 \\
\hline 60 & 458 & 187 & 7.1 & 80 & 5.4 & 89 \\
\hline \multicolumn{7}{|l|}{ Significance } \\
\hline Linear & $*$ & NS & NS & $* *$ & $* *$ & $*$ \\
\hline Quadratic & NS & NS & NS & NS & NS & $*$ \\
\hline
\end{tabular}

${ }^{2}$ Means of 1989 data only.

${ }^{y} \mathrm{MTG}=$ mean time to germination.

${ }^{\text {x} V i a b i l i t y ~ b y ~ t e t r a z o l i u m ~ t e s t . ~}$

Ns.,"** Nonsignificant or significant at $P \leq 0.05$ or 0.01 , respectively.

Table 3. Influence of fruit thinning at anthesis on bell pepper plant size and red fruit weight.

\begin{tabular}{lcccc}
\hline \hline $\begin{array}{l}\text { Fruit remaining } \\
\text { on plant }\end{array}$ & $\begin{array}{c}\text { Leaf area } \\
\left(1000 \mathrm{~cm}^{2}\right)\end{array}$ & $\begin{array}{c}\text { Plant dry } \\
\text { wt }(\mathrm{g})\end{array}$ & $\begin{array}{c}\text { Red fruit } \\
\text { wt }(\mathrm{g})\end{array}$ & $\begin{array}{c}\text { Leaf area : } \\
\text { total no. fruit } \\
\text { ratio }\end{array}$ \\
\hline All $^{2}$ & $5.34 \mathrm{~b}^{\mathrm{y}}$ & $66.0 \mathrm{~b}$ & $165 \mathrm{ab}$ & $485 \mathrm{C}$ \\
3 & $7.44 \mathrm{a}$ & $114 \mathrm{a}$ & $149 \mathrm{~b}$ & $3335 \mathrm{~b}$ \\
1 & $8.40 \mathrm{a}$ & $136 \mathrm{a}$ & $175 \mathrm{a}$ & $8397 \mathrm{a}$ \\
\hline
\end{tabular}

${ }^{2}$ Mean total number of fruit $=9$.

'Mean separation within columns by LSD, $P \leq 0.05$. comparable size with different fruit loads would produce seeds of comparable quality and 2) relationships on seed quality. Leaf area and plant dry weight increased as total fruit count decreased on the plant (Table 3). Removing fruit at anthesis increased pepper plant dry van Uffelen (1984) and Hurd et al (1979) (Lycopersicon esculentum Mill.). The anthesis, thinning had affected photosynthesis and photoassimilate partitioning significantly (Table 4). Smaller, nonthinned plants fixed C plants. Additionally, AER was $\approx 500 \%$ higher in nonthinned plants vs. thinned plants. These high sink demand and low ratios of leaf area to eaf CER and AER.

Plants that were thinned to three fruit produced significantly more seeds than those of other treatments (Table 5). Contrary to Wang found between treatments with regard to the number of seeds per red fruit or seed dry weight. Fruit load did not affect seed viability (Table 5). The germination percentage of seeds ever, was not consistent. At 50 days postobservations suggest that pepper plants with 
Table 4. Influence of fruit thinning on $\mathrm{C}$ exchange rate (CER) and assimilate export rate (AER) of bell pepper leaves at anthesis and at 50 days postanthesis harvest.

\begin{tabular}{lrrrr}
\hline Fruit remaining & \multicolumn{2}{c}{ Anthesis } & & Harvest \\
\cline { 2 - 3 } on plant & CER & AER & CER & AER \\
\hline & & $\left(m g \mathrm{CH}_{2} O /\right.$ dm $^{2}$ per $\left.h\right)$ & \\
All $^{2}$ & $4.41 \mathrm{a}^{\mathrm{y}}$ & $2.73 \mathrm{a}$ & $9.47 \mathrm{a}^{\mathrm{z}}$ & $5.39 \mathrm{a}$ \\
3 & $3.67 \mathrm{~b}$ & $2.62 \mathrm{a}$ & $.3 .05 \mathrm{~b}$ & $1.15 \mathrm{~b}$ \\
1 & $3.59 \mathrm{~b}$ & $1.97 \mathrm{~b}$ & $3.35 \mathrm{~b}$ & $1.17 \mathrm{~b}$ \\
\hline
\end{tabular}

${ }^{2}$ Mean total number of fruit $=9$.

${ }^{y}$ Mean separation within columns by LSD, $P \leq 0.05$.

Table 5. Influence of fruit thinning at anthesis on characteristics of seeds extracted from red bell peppers.

\begin{tabular}{lcccccc}
\hline \hline & \multicolumn{9}{c}{ Seed } & \\
\cline { 2 - 6 } $\begin{array}{l}\text { Fruit remaining } \\
\text { on plant }\end{array}$ & $\begin{array}{c}\text { Per plant } \\
(\text { no. })\end{array}$ & $\begin{array}{c}\text { Per fruit } \\
(\text { no. })\end{array}$ & $\begin{array}{c}\text { Dry wt } \\
(\mathrm{mg})\end{array}$ & $\begin{array}{c}\text { Germination } \\
(\%)\end{array}$ & $\begin{array}{c}\text { MTG }^{y} \\
(\text { days })\end{array}$ & $\begin{array}{c}\text { Viability }^{*} \\
(\%)\end{array}$ \\
\hline All & $365 \mathrm{~b}$ & $200 \mathrm{a}$ & $7.3 \mathrm{a}$ & $63 \mathrm{~b}$ & $7.1 \mathrm{~h}$ & $94 \mathrm{a}$ \\
3 & $483 \mathrm{a}$ & $188 \mathrm{a}$ & $7.4 \mathrm{a}$ & $82 \mathrm{a}$ & $7.4 \mathrm{~b}$ & $92^{\mathrm{a}}$ \\
1 & $223 \mathrm{~b}$ & $223 \mathrm{a}$ & $7.5 \mathrm{a}$ & $79 \mathrm{a}$ & $8.1 \mathrm{a}$ & $92 \mathrm{a}$ \\
\hline
\end{tabular}

${ }^{2}$ Mean total number of fruit $=9$.

${ }^{y} \mathrm{MTG}=$ mean time to germination.

${ }^{\mathrm{x}}$ Viability by tetrazolium test.

"Mean separation within columns by LSD, $P \leq 0.05$.

produced by nonthinned plants, however, was significantly lower than that of seeds in the other treatments. As in the plant density study, plant dry weight correlated $(P \leq 0.05)$ with seed germination percentage $(r=0.28)$.

The influence of plant density on seed development was unclear. Plant density did not affect the ratio of pepper leaf area to total fruit count significantly, yet larger plants (in $45-$ and $60-\mathrm{cm}$ spacing treatments) produced seeds that germinated faster and at higher percentages. Low plant densities resulted in larger plants that apparently transported photoassimilates from source leaves to sinks at higher rates than smaller plants. The primary influence of fruit thinning was to increase plant size and the ratio of leaf area to total fruit count, which in turn increased seed germination percentage. Smaller plants with high fruit loads responded to high sink demands by maintaining high CERS and AERs, yet these rates were insufficient to produce
Hesketh, J.D. and D.N. Moss. 1963. Variation in the response of photosynthesis to light. Crop Sci. 3:107-110.

Hurd, R. G., A.P. Gay, and A.C. Mountifield. 1979. The effect of partial flower removal on the relation between root, shoot and fruit growth in the indeterminate tomato. Ann. Applied Biol. 93:77-89.

Kriedemann, P.E., B.R. Possingham, and M. Satoh. 1976, Sink effects on stomatal physiology and photosynthesis, p. 401-414. In: I.F. Wardlaw and J.B. Passioura (eds.). Transport and transfer processes in plants. Academic, New York.

Nielsen, T. and B. Veierskov. 1988. Distribution of dry matter in sweet pepper plants (Capsicum annuиm L.) during the juvenile and generative growth phases. Sci. Hort. 35:179-187.

Osman, A. O., A. Raymond, and T. George. 1984. The effect of mineral nutrition and fruit position on seed yield and quality in sweet pepper ( Capsicum annuиm L.). VII. Tropical culture. Acts Hort. 143:133-137.

Palevitch, D. 1969. Varietal and spacing effects on the yield of red pepper (Capsicum annиит L.) in single harvest. Israel J. Agr. Res. 19:65-69.

Saamin, S. 1978. Effects of spacing, fertilizing and trimming on performance of three cultivars of peppers. MS Thesis, Louisiana State Univ., Baton Rouge.

seeds of similar quality as plants with lower sink demands. The germination percentage of seeds from smaller plants was significantly less than that of seeds from larger plants. The difference between viability and germination percentages of seeds produced by smaller plants in both studies is unclear, but may be due to increased seed dormancy. Therefore, crop cultural practices that increase pepper plant size may increase the quality of seeds produced by those plants.

\section{Literature Cited}

Edwards, R.L. and F.J. Sundstrom. 1987. Afterripening and harvesting effects on tabasco pepper seed germination performance. HortScience 22:473-475.

Grabe, D.F. 1970. Tetrazolium testing handbook. Assn. Offic. Seed Anal. Hdbk. Contrib. 29.

Hall, A.J. 1977. Assimilate source-sink relationships in Capsicum annuum L. I. The dynamics of growth in fruiting and deflorated plants. Austral. J. Plant Physiol. 4:623-636.
Sanchez, V.M. 1989. Enhancement of bell pepper seed quality by plant manipulation and harvest and postharvest handling treatments. MS Thesis. Louisiana State Univ., Baton Rouge.

SAS Institute. 1985. SAS users guide: Statistics. SAS Institute, Cary, N.C.

Steer, B.T. and C.J. Pearson. 1976. Photosynthate translocation in Capsicum annuum. Planta 128:155-162

Terry, N. and D.C. Mortimer. 1972. Estimate of the rates of mass carbon transfer by leaves of sugar beet. Can. J. Bet. 50: 1049-1054. cum. Proefstation voor de Tuinbouw onder Glas. Hort. Abstr. 55(8):1985.

van Uffelen, J.A.M. 1986. Fruit thinning of Capsicum. Proefstation voor de Tuinbouw onder Glas. Hort. Abstr. 56(10):9732.

Wang, Z., D. Wang, and H. Xylin. 1982. The effects of flower thinning of fruit and seed setting of sweet pepper. Acts Agr. Univ. Peking. Hort. Abstr. 53(6):4222. van Uffelen, J.A.M. 1984. Fruit thinning of Capsi- 